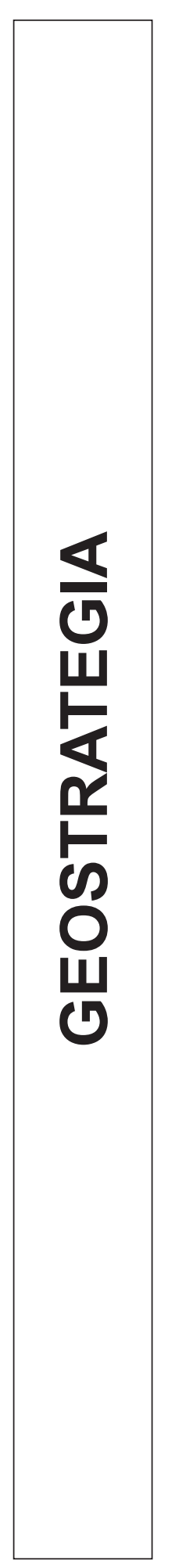





\section{Łukasz FIJAŁKOWSKI}

Uniwersytet Wrocławski

\section{TEORIA SEKURYTYZACJI I KONSTRUOWANIE BEZPIECZEŃSTWA}

Jeśli ważność teorii mierzyć jej popularnością wśród badaczy, to kluczowa dla tzw. szkoły kopenhaskiej teoria sekurytyzacji (ang. securitization) ${ }^{1}$ stanowi współcześnie jedno z ważniejszych podejść teoretycznych w studiach nad bezpieczeństwem międzynarodowym. Od lat dziewięćdziesiątych XX wieku teoria ta zdobywa coraz większa popularność, dzięki czemu poszerzony został jej zakres o nowe zagadnienia, początkowo wcale lub w niewielkim stopniu rozpatrywane. Należy również zauważyć, iż sama koncepcja nie ogranicza się wyłącznie do grupy badaczy wiązanych ze szkołą kopenhaska, i jest stałym elementem dyskusji na temat bezpieczeństwa międzynarodowego w jej teoretycznym i praktycznym wymiarze. Generalnie, debatę wokół sekurytyzacji można wpisać w trzy nurty kształtujące się od początku lat 2000 (czyli od momentu żywiołowego wzrostu zainteresowania tą koncepcją), które skupiają się na rozwijaniu, udoskonalaniu i/lub krytycznym wykorzystaniu teorii sekurytyzacji ${ }^{2}$. W pierwszym przypadku mamy do czynienia z dążeniem do nadania większej mocy eksplanacyjnej samej teorii. Część badaczy dąży zatem do rewizji teorii w celu uzyskania bardziej analitycznie użytecznych kryteriów służących osiągnięciu udanej sekurytyzacji ${ }^{3}$, podczas gdy inni skupiają się na mocy eksplanacyjnej teorii poza obszarem Zachodu ${ }^{4}$. W drugim przypadku debata toczy się wokół znaczenia i preferencji skierowanych na tzw. desekurytyzację, dążąc do ukazania normatywnych i politycznych implikacji tej kon-

1 W dalszej części tekstu będę się posługiwał terminem „,sekurytyzacja” wobec braku odpowiednika tego pojęcia w języku polskim. Próba przełożenia na j. polski i stosowanie np. terminu ,ubezpieczenie" (na zasadzie analogii do terminu politicisation thumaczonego przeze mnie jako „upolitycznienie”) brzmi dość niezręcznie. Nie należy w tym wypadku zatem mylić sekurytyzacji w studiach nad bezpieczeństwem z pojęciem sekurytyzacji z zakresu finansów. Jednocześnie, obok sekurytyzacji, używane będą pojęcia takie jak: aktor sekurytyzujący lub ruch sekurytyzujący, co wynika z tej samej przesłanki jak w przypadku sekurytyzacji, a także dla uniknięcia niejasności odnośnie stosowanych terminów.

2 Korzystam tutaj z podziału zaproponowanego w: U. P. Gad, K.L. Petersen, Concepts of politics in securitization studies, „Security Dialogue” 2011,vol. 42, no 4-5, s. 316-317.

${ }^{3}$ Np.: Th. Balzacq, The three faces of securitization: Political agency, audience and context, „European Journal of International Relations” 2005, vol. 11, no 2, s. 171-201; P. Roe, Actor, audien$c e(s)$ and emergency measures: Securitization and the UK's decision to invade Iraq, ,Security Dialogue" 2008, vol. 39, no 6, s. 615-635; H. Stritzel, Towards a theory of securitization: Copenhagen and Beyond, „European Journal of International Relations” 2007, vol. 13, no 3, s. 357-383.

${ }^{4} \mathrm{~Np}$. J. Vuori, Illocutionary logic and strands of securitization: Applying the theory of securitization to the study of non-democratic political orders, „European Journal of International Relations” 2008, vol. 14, no 1, s. 65-99; Non-traditional security in Asia: dilemmas in securitization, eds. M. C. Anthony, R. Emmers, A. Acharya, Aldershot 2006. 
cepcji. Cześć badaczy inspirując się krytycznymi studiami nad bezpieczeństwem, wyraża obawy o potencjał teorii $\mathrm{w}$ reprodukowaniu istniejącego liberalnego ładu w ramach koncepcji desekurytyzacji ${ }^{5}$, podczas gdy inni skupiają się na potencjale procesów sekurytyzacji/desekurytyzacji w dostarczaniu lub opisywaniu wiarygodnych strategii w stosunku do m.in. praw mniejszości lub AIDS ${ }^{6}$. Trzecia grupa skupia się na tym, jak ,mowa bezpieczeństwa” i praktyki elit państwowych łączą się w wymazywaniu rozróżnienia pomiędzy „wyjątkowością” a „normalnością?”. Głównym argumentem jest to, iż teoria sekurytyzacji nie jest w stanie uchwycić codziennej praktyki odnośnie nowych kwestii bezpieczeństwa i polityk wyrażających się w praktykach biurokratycznych (co jest w zasadzie pochodną skupienia się na sytuacji „nadzwyczajnej” jako początku sekurytyzacji) ${ }^{8}$. Szerzej linią krytyki jest niezdolność teorii do wyjścia poza nowoczesną formę rządzenia funkcjonalnie związaną z państwem narodowym?

Niemniej szczególnie w ostatnich latach zauważalny jest gwałtowny wzrost popularności teorii ${ }^{10}$, która wykorzystywana jest zarówno w debacie teoretycznej na temat bezpieczeństwa, jak i analizy praktyki międzynarodowej w tym zakresie. Stąd można zauważyć, iż teoria sekurytyzacji może być analizowana z przynajmniej dwóch perspektyw: teoretycznej (sekurytyzacja jako koncepcja na polu badań nad bezpieczeństwem) oraz praktycznej (sekurytyzacja jako narzędzie polityczne).

W ramach teorii sekurytyzacji można mówić o nowym podejściu do bezpieczeństwa, starającym się jednak równocześnie utrzymać jego analityczną użyteczność ${ }^{11}$. Stąd obiektem analizy jest nie tyle stan, ale przede wszystkim proces konstruowania „bezpieczeństwa”. Uwaga nie tyle skupia się na rozumieniu bezpieczeństwa jako „pewności istnienia i przetrwania" ${ }^{2}$, choć to ostatnie pojęcie zajmuje kluczowe miejsce $\mathrm{w}$ teorii. Teoria nie koncentruje się na rozumieniu bezpieczeństwa jako pojęciu obiektywnym, a raczej na intersubiektywnym procesie włączania/wyłączania niektórych zagadnień do sfery bezpieczeństwa. Uwaga jest skupiona na zmienności w cza-

5 C. Aradau, Security and the democratic scene: Desecuritization and emancipation, „Journal of International Relations and Development" 2004, vol. 7, no 4, s. 388-413.

${ }^{6}$ S. Elbe, Should HIV/AIDS be securitized? The ethical dilemmas linking HIV/AIDS and security, ,International Studies Quarterly” 2006, vol. 50, no 1, s. 119-144; P. Roe, Securitization and minority rights: Conditions of desecuritization, „Security Dialogue” 2004, vol. 35, no 3, s. 279-294.

7 J. Huysmans, The Politics of Insecurity: Fear, Migration and Asylum in the EU, London 2006; M. C. Williams, Words, images, enemies: Securitization and international politics, „International Studies Quarterly" 2003, vol. 47, no 4, s. 511-531.

${ }^{8}$ C. Aradau, Limits of security, limits of politics? A response, „Journal of International Relations and Development" 2006, vol. 9, no 1, s. 81-90; M. McDonald, Securitization and the construction of security, „European Journal of International Relations” 2008, vol. 14, no 4, s. 563-587.

9 J. Huysmans, The Politics of Insecurity: fear, migration and asylum in the EU, Routledge 2006.

10 W specjalnym numerze „Security Dialogue” z 2011 r., poświęconym w całości sekurytyzacji, zestawiono wzrost ilości artykułów poświęconych tej koncepcji od 1996 roku (w naukowych periodykach, jak i w referatach prezentowanych na międzynarodowych konferencjach ISA). Szerzej: U. P. Gad, K. L. Petersen, Concepts of politics in securitization studies, „Security Dialogue” 2011, vol. 42 , no $4-5$, s. 316.

11 Utrata analitycznej użyteczności jest częstym argumentem w debacie na temat tzw. poszerzania bezpieczeństwa.

12 R. Zięba, Pozimnowojenny paradygmat bezpieczeństwa międzynarodowego, w: Bezpieczeństwo międzynarodowe po zimnej wojnie, red. R. Zięba, Warszawa 2008, s. 16. 
sie tego, co jest rozumiane jako kwestia bezpieczeństwa, czyli podkreślona zostaje natura bezpieczeństwa jako „procesu społecznego"13. Istotne jest tutaj rozróżnienie między obiektywnym, subiektywnym i dyskursywnym rozumieniem bezpieczeństwa. Bezpieczeństwo w sensie obiektywnym zajmuje się brakiem zagrożeń dla danych wartości, a w rozumieniu subiektywnym, jest to brak obaw/strachu, że te wartości będą zagrożone $^{14}$. Dyskursywne ujęcia stwierdzają natomiast, iż niemożliwe jest zdefiniowanie bezpieczeństwa w sposób obiektywny, i generalnie obie poprzednie koncepcje są mylące. Istotne jest zrozumienie procesu, poprzez który dane zagrożenia manifestują się jako problemy bezpieczeństwa. Innymi słowy zagrożenia stają się „obiektywne", kiedy zostaną za takie uznane, a nie dlatego iż posiadają taką wrodzoną „właściwość" 15 . W tej sytuacji kluczowe staje się pytanie, w jaki sposób niektóre kwestie zostają włączone w sferę bezpieczeństwa i kto o tym decyduje. Teoria sekurytyzacji stara się skupiać na praktyce sekurytyzacji, odpowiadając na pytania kto „sekurytyzuje", w jakich kwestiach, w imieniu kogo/czego, dlaczego, z jakim skutkiem, i w jakich okolicznościach ${ }^{16}$. Tym samym odpowiedź na zagadnienie czym jest bezpieczeństwo uzależnione jest od jego stosowania. Oznaczenie danej kwestii jako kwestii bezpieczeństwa międzynarodowego staje się pochodną znaczenia jej nadawanego, tzn. iż dana kwestia ,jest ważniejsza od innych i powinna uzyskać absolutny priorytet”. Ostatecznie bezpieczeństwo odwołuje się do praktyki „samoodwoławczej” (ang. selfreferential practice), gdyż to dzięki niej dana kwestia staje się kwestią bezpieczeństwa (a niekoniecznie dlatego, iż mamy do czynienia z prawdziwym egzystencjalnym zagrożeniem) ${ }^{17}$.

\section{SZKOLA KOPENHASKA}

Początkowo teoria sekurytyzacji miała na celu wyjście w badaniach nad bezpieczeństwem poza sferę militarną przy zachowaniu odpowiednich kryteriów pozwalających odróżnić bezpieczeństwo od innych rodzajów polityki ${ }^{18}$. Tym samym koncepcja ta wpisała się w nurt poszerzający „tradycyjne” podejście do bezpieczeństwa. W latach 90. sekurytyzacja była jednym z trzech głównych zagadnień wyróżniających tzw. szkołę kopenhaską, wraz z koncepcją regionalnych kompleksów bezpieczeństwa i sektorów bezpieczeństwa ${ }^{19}$. Użycie po raz pierwszy samego terminu ,szkoła kopenhaska” przypisuje się Billowi McSweeney’owi, który posłużył się nim w 1996 roku²0 na okre-

13 Ibidem.

14 A. Wolfers, ,, National Security” as an Ambiguous Symbol, „Political Science Quarterly” 1952, vol. 67, no 4, s. 485.

15 B. Buzan, L. Hansen, The Evolution of International Security Studies, Cambridge 2009, s. $32-33$.

16 B. Buzan, O. Wæver, J. De Wilde, Security: A New Framework for Analysis, Boulder, CO 1998 , s. 32.

17 Ibidem, s. 24.

18 Gad, Petersen, op. cit., s. 315.

19 W. Kostecki, Europe after the Cold War. The security complex theory, Warszawa 1996, s. $15-21$.

20 B. McSweeney, Identity and security: Buzan and the Copenhagen School, „Review of International Studies" 1996, vol. 22, no 1, s. 81-94. 
ślenie grupy badaczy skupionych w COPRI (ang. Conflict and Peace Research Institute) w Kopenhadze, do której zaliczyć należy m.in. Barry Buzana, Ole Wævera, Jaap de Wilde i innych ${ }^{21}$. Pojęcie szkoły należy w tym wypadku traktować raczej jako pewnego rodzaju metaforę, oznaczającą ,szkołę myślenia”, niekoniecznie związaną wyłącznie z konkretnym ośrodkiem (choć $\mathrm{w}$ celu uchwycenia różnic w ramach krytycznych studiów nad bezpieczeństwem wyróżniono szkołę kopenhaską, walijską i paryską, jednak wzajemne powiązania między nimi są dość silne ${ }^{22}$ ). W przypadku samej teorii sekurytyzacji szczególnie ważna jest osoba Ole Wævera, właściwego twórcy koncepcji (w chwili obecnej dyrektora CAST - ang. Centre for Advanced Security Theory na Uniwersytecie w Kopenhadze). Szkoła kopenhaska odegrała istotną rolę w poszerzeniu koncepcji bezpieczeństwa i w stworzeniu ram analizy jak dana kwestia podlega sekurytyzacji i desekurytyzacji. Obiektem zainteresowania stał się sam proces, w jakim pewne kwestie stają się częścią sfery bezpieczeństwa. W ten sposób bezpieczeństwo nie było traktowane jako obiektywny fakt, lecz swoista konstrukcja wypływająca z interakcji społecznych. Żadnej kwestii nie można traktować tutaj jako przynależnej do sfery bezpieczeństwa a priori, niejako ze swojej natury. Jest do niej włączana poprzez proces sekurytyzacji. Mając to na uwadze zrozumiałe jest, iż wśród źródeł samej koncepcji wymieniany jest m.in. konstruktywizm, a sama teoria zaliczana jest do podejść konstruktywistycznych w badaniach nad bezpieczeństwem ${ }^{23}$. Niemniej teoria sekurytyzacji czerpie także z innych podejść i teorii, co wynika z samej ewolucji koncepcji, jak i wpływu, jaki wywarły na Ole Wævera rozmaite teorie, począwszy od realizmu strukturalnego Kennetha Waltza, a skończywszy na teorii aktu mowy Johna L. Austina. Jednocześnie dalsze wykorzystanie teorii dotyczy bardzo zróżnicowanych zagadnień, co może spotykać się także z zarzutem zbyt daleko idącego stosowania teorii w nie zawsze adekwatnych przypadkach.

\section{TEORIA SEKURYTYZACJI}

Teoria sekurytyzacji wpisuje się w nurt poszerzający rozumienie bezpieczeństwa, uznający potrzebę jego rozpatrywania nie tylko w kontekście zagrożeń militarnych. Wynikało to m.in. ze zmian, jakie zaszły w środowisku międzynarodowym w latach osiemdziesiątych i dziewięćdziesiątych XX wieku, ale również ze wzrastającego znaczenia czynników środowiskowych i ekonomicznych, a także rozszerzania pojęcia bezpieczeństwa przez np. polityków przez wykorzystywanie go w odwoływaniu się do

${ }^{21}$ O. Wæver, Securitization and desecuritization, w: On Security, ed. R. D. Lipschutz, New York 1995, s. 46-86; B. Buzan, O. Wæver, J. De Wilde, op. cit.; B. Buzan, O. Wæver, Regions and Powers. The Structure of International Security, Cambridge 2003.

22 O. Wæver, Aberystwyth, Paris, Copenhagen: New 'schools' in security theory and their origins between core and periphery, paper presented at the Annual Convention of the International Studies Association, Montreal, 17-20 March 2004; C. Peoples, N. Vaughan-Williams, Critical Security Studies. An introduction, London-New York 2010, s. 9-11; C.A.S.E. Collective, Critical Approaches to Security in Europe: A Networked Manifesto, ,Security Dialogue” 2005, vol. 37, no 4, s. 443-487.

23 M. McDonald, Constructivism, w: Security Studies: An Introduction, ed. P. D. Williams, London-New York 2008, s. 68-71. 
różnorodnych kwestii. Jednak jak podkreśla $\mathrm{O}$. Wæver, pojęcie bezpieczeństwa ma swoją historię i zestaw powiązań od których nie można uciec, i stąd w pierwszym rzędzie odnosi się ono do państwa, oraz oznacza specyficzny obszar praktyki ${ }^{24}$. Dlatego podkreślając chęć zachowania analitycznej użyteczności koncepcji bezpieczeństwa i uniknięcia zbytniego jej rozszerzenia, kwestie podlegające sekurytyzacji w przypadku szkoły kopenhaskiej ograniczono przede wszystkim do „zagrożeń o charakterze egzystencjalnym". Sekurytyzacja odnosi się do refleksyjnej konstrukcji polityki rozumianej jako publiczna arena, gdzie interakcje między państwem a społeczeństwem są uprzednio zdeterminowane przez kwestie bezpieczeństwa ${ }^{25}$. W ten sposób teoria sekurytyzacji jednocześnie poszerza bezpieczeństwo o nowe sektory i aktorów (uprzywilejowując jednak niektórych - zwłaszcza państwowych, co dla niektórych jest punktem oparcia dla krytyki), ograniczając je równocześnie do sfery działań nadzwyczajnych i do kwestii związanych z przetrwaniem (czyli w znacznym stopniu zagadnień tradycyjnie wpisujących się $\mathrm{w}$ rozumienie bezpieczeństwa narodowego skupionego na państwie i zagrożeniach militarnych).

Teoria sekurytyzacji sukcesywnie była rozwijana przez szkołę kopenhaską w licznych publikacjach, a szczególne znaczenie ma tutaj książka Security: A New Framework for Analysis. Bezpieczeństwo wprost zostało powiązane z przetrwaniem, dając punkt wyjścia dla dalszych rozważań, a także prezentując jego podstawowy sposób definiowania (ang. security is about survival). W efekcie jest możliwe oraz uzasadnione użycie nadzwyczajnych środków, gdyż „dana kwestia jest zaprezentowana jako stwarzająca zagrożenie egzystencjalne dla wyznaczonego obiektu (ang. referent object) (tradycyjnie, lecz nie zawsze, państwa, w tym rządu, terytorium i społeczeństwa)"26. Jednocześnie „coś jest określane jako kwestia bezpieczeństwa międzynarodowego, ponieważ można twierdzić, iż ta kwestia jest ważniejsza od innych, i powinna mieć absolutny priorytet" ${ }^{27}$. Stąd bezpieczeństwo jest widoczne poprzez praktykę, przez zaprezentowanie danej kwestii jako zagrożenia, a niekoniecznie poprzez istnienie prawdziwego zagrożenia egzystencjalnego ${ }^{28}$.

Szkoła kopenhaska, idąc w ślady wydzielonych przez Barry'ego Buzana ${ }^{29}$ sektorów bezpieczeństwa, wyznacza 5 ogólnych kategorii bezpieczeństwa: militarnego, politycznego, ekonomicznego, społecznego i środowiskowego. Dynamika bezpieczeństwa w każdej kategorii jest wyznaczana przez aktorów sekurytyzujących i obiekty bezpieczeństwa (ang. referent objects). W zależności od danego sektora procesy sekurytyzacji będą się różnić, co pozwala na rozszerzenie rozumienia bezpieczeństwa, podtrzymując jednak centralną rolę „zagrożenia egzystencjalnego” w jego wyznaczaniu. Niemniej jednak w każdym przypadku inne kwestie mogą mieć charakter egzystencjalny, tak samo jak zróżnicowany będzie każdorazowo sam obiekt bezpieczeństwa (tab. 1). Seku-

${ }^{24}$ O. Wæver, Securitization and desecuritization, op. cit., s. 46-86.

25 R. Taureck, Securitization theory and securitization studies, ,Journal of International Relations and Development" 2006, vol. 9, no 1, s. 54-55.

${ }^{26}$ B. Buzan, O. Wæver, J. De Wilde, op. cit., s. 21.

27 Ibidem, s. 24.

28 Ibidem.

29 B. Buzan, People, States and Fear: An Agenda for International Security Studies in the Post-Cold War Era, London 1991. 
rytyzacja zakłada również istnienie co najmniej dwóch stron procesu: jednej odpowiedzialnej za przedstawienie danej kwestii jako egzystencjalnego zagrożenia i drugiej, która jest zagrożona, stanowiące razem jednostki analizy bezpieczeństwa ${ }^{30}$. Innymi słowy są to tzw. aktor sekurytyzujący i obiekt bezpieczeństwa.

Tabela 1

\section{Dynamika sekurytyzacji a sektory bezpieczeństwa}

\begin{tabular}{||l|l|l||}
\hline \multicolumn{1}{|c|}{ Sektor } & \multicolumn{1}{|c|}{ Rodzaj interakcji } & \multicolumn{1}{|c||}{ Dynamika sekurytyzacji } \\
\hline Militarny & Relacje oparte na przymusie & $\begin{array}{l}\text { Egzystencjalne zagrożenie dla państwa/ludności/ teryto- } \\
\text { rium/możliwości wojskowych }\end{array}$ \\
\hline Polityczny & $\begin{array}{l}\text { Relacje oparte na władzy, rządzeniu, } \\
\text { uznaniu }\end{array}$ & $\begin{array}{l}\text { Egzystencjalne zagrożenie dla suwerenności/stabilności } \\
\text { porządku społecznego }\end{array}$ \\
\hline Ekonomiczny & $\begin{array}{l}\text { Relacje oparte na handlu, produkcji } \\
\text { i finansach }\end{array}$ & $\begin{array}{l}\text { Egzystencjalne zagrożenie dla rynków/finansów/za- } \\
\text { sobów }\end{array}$ \\
\hline Społeczny & $\begin{array}{l}\text { Relacje oparte na kolektywnej tożsa- } \\
\text { mości }\end{array}$ & $\begin{array}{l}\text { Egzystencjalne zagrożenie dla kolektywnej tożsamo- } \\
\text { ści/języka/kultury }\end{array}$ \\
\hline Środowiskowy & $\begin{array}{l}\text { Relacje między aktywnością ludzką } \\
\text { a ziemską biosferą }\end{array}$ & $\begin{array}{l}\text { Egzystencjalne zagrożenie dla biosfery/gatunków/środo- } \\
\text { wiska naturalnego }\end{array}$ \\
\hline
\end{tabular}

Źródło: C. Peoples, N. Vaughan-Williams, op. cit., s. 80.

W całym procesie sekurytyzacji kluczowa rola przypada aktorowi sekurytyzujacemu ${ }^{31}$. Jest to aktor, „który sekurytyzuje daną kwestię poprzez zadeklarowanie, iż obiekt bezpieczeństwa jest egzystencjalnie zagrożony"32. Najczęściej będą taką rolę pełnić ,liderzy polityczni, biurokracja, rząd, grupy lobbujące i grupy nacisku"33. Ruch sekurytyzacyjny, który rozpoczyna cały proces, ma przyjmować postać aktu mowy, co jest przez niektórych badaczy przedmiotem krytyki. Podkreśla się w tym przypadku potrzebę dalszej konceptualizacji tej kwestii, m.in. z powodu wątpliwości czy akt sekurytyzacyjny musi mieć charakter jednorazowy, oraz czy w świecie zdominowanym przez przekaz wizualny, obraz może odgrywać rolę zarezerwowaną dotychczas dla przekazu słownego (zdjęcia, multimedia, rysunek itp.) ${ }^{34}$.

Równie istotny dla teorii sekurytyzacji jest obiekt bezpieczeństwa ${ }^{35}$. Są ,to rzeczy postrzegane jako egzystencjalnie zagrożone i które mają legitymowane prawo do przetrwania"36. Przedmiot bezpieczeństwa oraz rodzaj zagrożenia może znacznie się różnić w zależności od sektora, począwszy od państwa (bezpieczeństwo militarne), narodo-

${ }^{30}$ W. Kostecki, op. cit. s. 48.

31 B. Buzan, O. Wæver, J. De Wilde, op. cit., s. 40-42.

Ibidem, s. 36.

33 Ibidem, s. 40.

34 L. Hansen, Theorizing the image for Security Studies: Visual securitization and the Muhammad Cartoon Crisis, „European Journal of International Relations” 2011, vol. 17, no 1, s. 51-74; McDonald, Securitization and the construction of security, „European Journal of International Relations” 2008, vol. 14, no 4, s. 563-587; M. C. Williams, Words, images, enemies: Securitization and international politics, „International Studies Quarterly” 2003, vol. 47, no 4, s. 511-531.

35 B. Buzan, O. Wæver, J. De Wilde, op. cit., s. 36-40.

36 Ibidem, s. 36 
wej suwerenności lub ideologii (bezpieczeństwo polityczne), narodowej gospodarki (bezpieczeństwo ekonomiczne), kolektywnych tożsamości (bezpieczeństwo społeczne), a na gatunkach i habitatach skończywszy (bezpieczeństwo środowiskowe) ${ }^{37}$.

Zaskakujące jest, iż zdecydowanie mniej miejsca poświęca się równie istotnym elementom teorii sekurytyzacji, tzn. odbiorcom (ang. audience) oraz czynnikom ułatwiającym sekurytyzację (ang. facilitating conditions) ${ }^{38}$. W pierwszym wypadku mając na uwadze charakter całego procesu, tzn. iż ruch sekurytyzacyjny jest zawsze skierowany w czyimś kierunku, w stronę konkretnego adresata, wzrasta tym samym jego rola - widoczne to jest przy rozpatrywaniu sytuacji sukcesu lub porażki sekurytyzacji. Tym samym część wysiłku w rozwoju teorii została skierowana na dalszą konceptualizację tego zagadnienia. Jednocześnie sekurytyzacja odbywa się zawsze w określonym kontekście, a co za tym idzie, można założyć, iż niektóre uwarunkowania mogąjej sprzyjać lub nie. Początkowo temu zagadnieniu również nie poświęcono wiele uwagi.

\section{SEKURYTYZACJA I DESEKURYTYZACJA}

Określając czym jest sama sekurytyzacja, należy podkreślić, iż w ujęciu szkoły kopenhaskiej stanowi ona przypadek skrajnego upolitycznienia, zajmujący krańcową pozycję w spektrum kwestii „nieupolitycznionych” (dana kwestia nie stanowi przedmiotu działań państwa i nie jest częścią publicznej debaty), „upolitycznionych” (kwestia jest częścią standardowych politycznych procedur i jest ona „częścią publicznej polityki, wymagającej decyzji rządowych i alokacji zasobów lub rzadziej innych form rządzenia" ${ }^{39}$ ) i podlegających sekurytyzacji (w momencie gdy dana kwestia wymaga działań wykraczających poza standardowe procedury polityczne). Zatem sekurytyzacja może zostać zdefiniowana jako określenie poprzez akt mowy (zazwyczaj przez lidera politycznego) danej kwestii jako zagrożenia dla przetrwania, co następnie pozwala (za zgodą istotnej grupy odbiorców) na użycie nadzwyczajnych środków i zawieszenie procedury „normalnej polityki” w celu poradzenia sobie z tą kwestią ${ }^{40}$.

Dana kwestia może zostać zsekurytyzowana (przesunięta do sfery bezpieczeństwa) poprzez tzw. ruch sekurytyzacyjny. Aktor sekurytyzujący wskazuje na upolitycznioną już wcześniej kwestię jako zagrożenie egzystencjalne dla obiektu bezpieczeństwa. W odpowiedzi na egzystencjalną naturę zagrożenia, aktor sekurytyzujący zapewnia, iż należy przyjąć nadzwyczajne środki wykraczające poza normalne procedury. Sekurytyzacja ,jest działaniem, które wykracza poza ustalone normy polityki i oznacza daną kwestię zarówno jako specjalny przypadek polityki, jak i wykraczający poza nia. Sekurytyzacja może być zatem postrzegana jako bardziej skrajna wersja upolitycznienia",41. Odwrotnym procesem będzie desekurytyzacja, która obejmuje ,przeniesienie kwestii

37 Ibidem.

38 M. McDonald, Securitization and the construction of security, op. cit., s. 563-587.

39 B. Buzan, O. Wæver, J. De Wilde, op. cit., s. 23.

40 M. McDonald, Securitization and the construction of security, op. cit., s. 567.

41 B. Buzan, O. Wæver, J. De Wilde, op. cit., s. 23. 
spoza polityki nadzwyczajnej w normalną sferę polityki" ${ }^{42}$. Należy tu zaznaczyć, iż to desekurytyzacji jest działaniem preferowanym, w związku z tym, iż „bezpieczeństwo” generalnie nie jest uznawane za pozytywną kwestię. Sekurytyzacja prowadząca do włączenie pewnej kwestii w sferę bezpieczeństwa jest $w$ istocie porażka standardowych procedur, czyli najbardziej pożądanym kierunkiem działań będzie powrót do sfery polityki $^{43}$. Dla Ole Wævera postrzeganie bezpieczeństwa jako uniwersalnie pozytywnej kwestii - pożądanego stanu rzeczy, do którego powinno się zmierzać - jest krótkowzroczne, gdyż w przypadku bezpieczeństwa mamy do czynienia w najlepszym razie ze stabilizacją relacji konfliktowych, często poprzez nadzwyczajne działania państwa. Stąd właśnie lepiej jest myśleć tutaj w kategoriach zmierzania do desekurytyza$\mathrm{cji}^{44}$. Innymi słowy, bezpieczeństwo oznacza sytuację, gdzie mamy do czynienia z obecnością problemu związanego z bezpieczeństwem i odpowiednimi środkami przedsiębranymi w odpowiedzi na nie. W innym wypadku mamy do czynienia $\mathrm{z}$ sytuacją braku bezpieczeństwa (ang. insecurity), gdzie dany problem nie spotyka się z odpowiedzią ${ }^{45}$. Natomiast desekurytyzacja prowadzi do całkowitego wyjścia ze sfery bezpieczeństwa.

Sekurytyzacja odnosi się do dwustopniowego procesu mającego wyjaśnić jak i kiedy dana kwestia jest postrzegana jako egzystencjalne zagrożenie dla bezpieczeństwa, i co za tym idzie, jak i kiedy staje się przedmiotem odpowiednich działań. Pierwszy etap dotyczy określenia danej kwestii jako zagrożenia egzystencjalnego dla obiektu bezpieczeństwa. Pierwszy krok może zostać zainicjowany przez państwa, lecz także przez aktorów niepaństwowych, jak związki zawodowe lub ruchy społeczne. Jednak sekurytyzacja jest procesem zdominowanym raczej przez potężniejszych aktorów czerpiących korzyści z uprzywilejowanej pozycji. Ruch sekurytyzacyjny zależy od władzy i wpływu aktora sekurytyzującego, jednocześnie je ujawniającym. Tym samym uwidacznia/potwierdza się uprzywilejowana pozycja niektórych aktorów, głównie państwowych. Można powiedzieć, iż teoria sekurytyzacji nie ma charakteru wyraźnie państwocentrycznego, lecz jednocześnie widocznie premiuje państwa ${ }^{46}$. O. Wæver zauważa, iż pomimo że na bezpieczeństwo ma wpływ dynamika z poziomu jednostkowego, jako koncepcja bezpieczeństwo odnosi się do państwa i jego działań na arenie międzynarodowej.

Wykorzystywanie języka „bezpieczeństwa” nie oznacza automatycznego przekształcenia danej kwestii w kwestię bezpieczeństwa. Aby wytworzyć odpowiedni efekt, istotne jest przekonanie odbiorców przekazu do działań aktora sekurytyzującego i jego zaakceptowanie przez nich (tzn. przez odbiorców). Stąd drugi etap sekurytyzacji jest zakończony sukcesem jedynie w sytuacji, gdy ,istotny” odbiorca zostanie przekonany i zaakceptuje obraz egzystencjalnego zagrożenia dla obiektu bezpieczeństwa. Tylko w tym wypadku mogą zostać podjęte nadzwyczajne środki, gdyż w tej sytuacji „nagłość” sytuacji wymusza zaakceptowanie środków wykraczających poza normalne

42 Ibidem, s. 4.

43 B. Buzan, Rethinking Security after the Cold War, „Cooperation and Conflict” 1997, vol. 32, no 1 .

44 Ibidem, s. 11.

45 O. Wæver, Securitization and desecuritization, op. cit., s. 56.

46 R. Wyn Jones, Security, Strategy, and Critical Theory, London 1999. 
procedury. Choć tutaj wprost przedstawiciele szkoły kopenhaskiej mówią, iż „nie stawiają tak wysokich wymogów, aby oczekiwać że nadzwyczajne środki muszą zostać przyjęte" ${ }^{47}$, lecz mogą stanowić podstawę pod możliwe ich zastosowanie. Zatem udana sekurytyzacja składa się z trzech części:

1) wskazania zagrożenia egzystencjalnego;

2) odwołania się do nadzwyczajnych działań;

3) wpływ na relacje między jednostkami poprzez swobodne złamanie zasad ${ }^{48}$.

W ten sposób dyskurs w obrębie bezpieczeństwa podkreślając kwestie egzystencjalne wychodzi ponad politykę, a dana kwestia zostaje ,udramatyczniona i przedstawiona jako mająca nadrzędne znaczenie”, czyli aktor odwołując się do bezpieczeństwa zgłasza roszczenie oraz prawo do wykorzystania nadzwyczajnych środków. Dla badacza ważne nie jest tutaj określenie rzeczywistych zagrożeń, a raczej zrozumienie procesu konstruowania „wspólnego rozumienia” tego, co jest uznawane i kolektywnie traktowane jako zagrożenie. Bezpieczeństwo w ten sposób zostaje powiązane z aktem mowy (zostało to odzwierciedlone w słowach Ole Wævera: by saying the words, something is done $)^{49}$.

W centrum procesu sekurytyzacji znajduje się tzw. akt mowy, rozumiany jako dyskursywna reprezentacja danej kwestii jako egzystencjalnego zagrożenia dla bezpieczeństwa. Szkoła kopenhaska zakłada, iż akt mowy stanowi początek całego procesu, stąd można spotkać się pojęciem „bezpieczeństwa jako aktu mowy”, gdzie poprzez odwołanie się do „bezpieczeństwa” coś zostaje dokonane. „Poprzez określenie czegoś jako kwestii bezpieczeństwa to coś nią się staje" ${ }^{50}$. Dana kwestia staje się kwestią bezpieczeństwa poprzez akt mowy niezależnie od tego, czy mamy do czynienia z rzeczywistym odzwierciedleniem egzystencjalnego zagrożenia w warunkach materialnych. Aktor sekurytyzujący wykorzystuje język do wyartykułowania problemu w odpowiedni sposób (w ,języku bezpieczeństwa") i przekonania właściwego odbiorcy o bezpośrednim zagrożeniu. Artykułowanie w odpowiedni sposób (w języku bezpieczeństwa) warunkuje odbiorców i daje aktorowi prawo do zmobilizowania zasobów państwowych i wykroczenie poza tradycyjne i standardowe zasady.

Udany akt sekurytyzacji zależy od zaakceptowania przez odbiorcę przedstawionej sprawy jako zagrożenia egzystencjalnego. W przypadku państw demokratycznych możliwość odrzucenia ruchu sekurytyzacyjnego jest możliwa w większym stopniu niż w przypadku innych reżimów (tutaj odbiorca może być inny niż w pierwszym przypad$\mathrm{ku})$. O ile w reżimach demokratycznych odbiorcą zazwyczaj będzie całe społeczeństwo, to np. w reżimach autorytarnych cały proces sekurytyzacji będzie mógł mieć miejsce w obrębie elit politycznych. Jednocześnie można się zastanawiać, na ile cały proces akceptacji ruchu sekurytyzującego będzie przyjmował postać automatycznej zgody na wszystko to, co zostanie przedstawione przez aktora sekurytyzującego jako zagrożenie egzystencjalne (stąd w praktyce można by pominąć ten etap - sekurytyzacja wiązałaby się z jednostronnym działaniem aktora sekurytyzującego, dostarczając mu

\footnotetext{
47 B. Buzan, O. Wæver, J. De Wilde, op. cit., s. 25.

48 Ibidem, s. 26

49 Ibidem.

50 O. Wæver, Aberystwyth, Paris, Copenhagen, op. cit., s. 13.
} 
odpowiedniego uzasadnienia dla własnych działań; dlatego teoria sekurytyzacji w większym stopniu wydaje się odnosić do reżimów demokratycznych, pozwalających na szersze spojrzenie na to zagadnienie).

Szkoła kopenhaska postrzega bezpieczeństwo jako koncepcję społecznie konstruowaną. W tym sensie ma ona związek z konstruktywizmem. Przez to kwestia tego, co konstytuuje zagrożenie egzystencjalne jest kwestią intersubiektywną. Zależy w dużym stopniu na wspólnym rozumieniu tego co konstytuuje zagrożenie dla bezpieczeństwa. Osoba posiadająca władzę najpierw potrzebuje posłużyć się ,językiem bezpieczeństwa" i zażądać zastosowania nadzwyczajnych środków. Dyskurs aktora sekurytyzującego musi zostać wyartykułowany w taki sposób, jaki może przekonać odbiorcę. Każdy akt sekurytyzacji dotyczy decyzji politycznej i wynika z aktu politycznego oraz społecznego. Szkoła kopenhaska uznaje, iż akt sekurytyzacji może się powieść lub ponieść porażkę w zależności od zaakceptowania danego dyskursu przez odbiorcę. Pojawia się jednak pytanie dlaczego niektóre kwestie w pierwszym rzędzie ulegają sekurytyzacji, co niekoniecznie jest odzwierciedleniem czynników materialnych. Częściową odpowiedź można znaleźć po stronie praktyki, włączającej niektóre kwestie w „naturalny" sposób (a przynajmniej tak jest to traktowane) w sferę bezpieczeństwa.

Dodatkowo relacje pomiędzy podmiotami nie mają charakteru symetrycznego, stąd możliwość udanej sekurytyzacji będzie się znacznie różnić w zależności od pozycji zajmowanej przez danego aktora. W związku z tym bezpieczeństwo ma charakter „ustrukturyzowany”, gdzie niektórzy aktorzy są uprzywilejowani dzięki zaakceptowaniu ich jako głosów przemawiających w języku bezpieczeństwa, dzięki władzy definiowania bezpieczeństwa ${ }^{51}$. Stąd aktorzy zajmujący się bezpieczeństwem (zwłaszcza w sektorze militarnym i politycznym) cieszą się odpowiednią pozycją i legitymizacją (można zaryzykować stwierdzenie, iż w takiej sytuacji sekurytyzacja została dokonana wcześniej i została wbudowana w strukturę relacji społecznych i politycznych). W centrum zainteresowania analizy jest praktyka sekurytyzacji, a nie aktorzy. W przypadku sekurytyzacji jako „czynniki ułatwiające” akt wymieniane są: 1) przestrzeganie w ramach aktu mowy „gramatyki” bezpieczeństwa; 2) społeczne warunki odnośnie pozycji władzy aktora sekurytyzującego - relacji między mówcą a odbiorcą i co za tym idzie, prawdopodobieństwa zaakceptowania przez odbiorcę roszczeń czynionych w imię sekurytyzacji; 3) cechy danego zagrożenia, które mogą ułatwiać lub utrudniać sekurytyzację $e^{52}$.

\section{ŹRÓDLA TEORII SEKURYTYZACJI}

Jako źródła teorii sekurytyzacji, zarówno przez bezpośrednie odwołania, jak i miejsce czerpania inspiracji w przypadku Ole Wævera, można wymienić m.in. prace Johna L. Austina, Carla Schmitta, Kennetha Waltza i Jacquesa Derridę ${ }^{53}$. Jednocześnie samo podejście zaliczane jest do umiarkowanego konstruktywizmu, ale można się spotkać

\footnotetext{
51 B. Buzan, O. Wæver, J. De Wilde, op. cit., s. 31.

52 Ibidem, s. 33.

53 O. Wæver, Aberystwyth, Paris, Copenhagen, op. cit., s. 13.
} 
również z określeniem nurtu reprezentowanego przez Ole Wævera jako poststrukturalnego realizmu - zajmującego miejsce między głównym nurtem stosunków międzynarodowych a poststrukturalizmem ${ }^{54}$. Poststrukturalny realizm posiada tutaj podwójne znaczenie, tzn. może oznaczać ,poststrukturalne odczytanie realizmu” oraz teorię zajmującą pozycję ,po" waltzowskim strukturalnym realizmie. Niemniej pomimo tej prowokacyjnej nazwy sama teoria sekurytyzacji umieszczana jest na skraju realizmu i poststrukturalizmu, i zaliczana jest do drogi ,środka” między dwoma ekstremami, czyli właśnie do umiarkowanego konstruktywizmu ${ }^{55}$.

Związki między teorią sekurytyzacji wypracowaną przez O. Wævera a Jacquesem Derridą mają głównie charakter inspiracji na poziomie metateoretycznym ${ }^{56}$. Natomiast wyraźniejsze związki są widoczne odnośnie J. Austina, C. Schmitta i K. Waltza.

W przypadku Johna L. Austina mamy do czynienia z jednoznacznym wykorzystaniem teorii aktu mowy w odniesieniu do bezpieczeństwa rozumianego właśnie jako akt mowy. Istotne jest tutaj założenie, iż przy pomocy języka można tworzyć fakty społeczne (chodzi tutaj o ideę wypowiedzi performatywnych oraz akty mowy dzielące się na akty lokucyjne, illokucyjne i perlokucyjne). Teoria sekurytyzacji przede wszystkim nawiązuje do illokucyjnych aktów mowy (są to akty posiadające pewną konwencjonalną moc, intencjonalność wypowiedzi, np. informowanie, nakazywanie, obiecywanie, ostrzeganie). Bezpieczeństwo ma tutaj charakter illokucyjny i jest osiagane przez „wypowiedzenie” bezpieczeństwa. Również warunki ułatwiające akt sekurytyzacji nawiązują do J. Austina ${ }^{57}$.

Można również dostrzec związek między teorią sekurytyzacji a pracami Carla Schmitta, szczególnie z powodu roli nadawanej nadzwyczajnym działaniom wykraczającym poza normalne procedury. Za główny punkt styczny teorii sekurytyzacji i myśli C. Schmitta uznać można odwoływanie się do „egzystencjalnego zagrożenia” jako podstawy stworzenia kwestii bezpieczeństwa. Zagrożenie egzystencjalne staje się warunkiem wstępnym i niezbędnym, stąd sekurytyzacja odzwierciedla linie wewnętrznych podziałów istotnych dla koncepcji polityczności stworzonej przez C. Schmitta. „Ten, kto decyduje o stanie wyjątkowym, jest suwerenny" ${ }^{\text {" }}$ - słowa te podkreślają rolę tego, kto sprawuje władzę, a także znaczenie nadzwyczajnej polityki, w trakcie której objawia się pełnia suwerenności jako możliwość podejmowania decyzji. Proces sekurytyzacji w swojej logice idzie zgodnie z tym samym tokiem rozumowania - aktor sekurytyzujący objawia swoją władzę poprzez legitymizowane działania w „nadzwyczajnych" warunkach ${ }^{59}$.

54 W. Kostecki, op. cit., s. 8-11.

55 R. Taureck, Securitization theory - The Story so far: Theorethical inheritance and what it means to be a post-structural realist, paper for presentation at the $4^{\text {th }}$ annual CEEISA convention, University of Tartu, 25-27 June 2006; B. Buzan, O. Wæver, op. cit., s.71.

56 R. Taureck, Securitization theory - The Story so far, op. cit.

57 Thierry Balzacq przekonuje jednak, iż mamy w przypadku sekurytyzacji raczej do czynienia z perlokucyjnym aktem mowy (tzn. wywierającym pewien określony skutek, gdzie wypowiedź wywołuje u odbiorcy jakiś efekt, np. zaskakiwanie kogoś, oszukiwanie, przekonywanie). Patrz: Th. Balzacq, op. cit., s. 171-201.

${ }_{58}$ C. Schmitt, Teologia polityczna i inne pisma, Kraków 2000, s. 33.

59 M. C. Williams, Words, images, enemies, op. cit., s. 515-521. 
Rola teorii strukturalnej Kennetha Waltza dla koncepcji sekurytyzacji wynika z roli jaką jej nadaje $\mathrm{O}$. Wæver jako początek własnej refleksji i analizy, wraz z podejściem $\mathrm{K}$. Waltza do zagadnienia czym jest teoria (iż nie może obejmować wszystkiego i ma własne ograniczenia). Poza tym wpływ na sekurytyzację ma występujący u K. Waltza związek między przetrwaniem a bezpieczeństwem (, przetrwanie jest podstawą działania w świecie, gdzie bezpieczeństwo państw nie jest zapewnione" ${ }^{\circ 0}$ ), a dla O. Wævera „,bezpieczeństwo oznacza przetrwanie w obliczu egzystencjalnych zagrożeń" ${ }^{61}$. Dodatkowo sugestią związków jest to, kto najprawdopodobniej w udany sposób przeprowadzi proces sekurytyzacji, tzn. „warunki społeczne odnośnie pozycji władzy aktora sekurytyzującego" ${ }^{62}$ mają charakter bliski realistycznemu spojrzeniu na dystrybucję władzy w ramach systemu. Im więcej aktor posiada możliwości działania (władzy) tym bardziej prawdopodobne, iż uda mu się przeprowadzić sekurytyzację.

Teoria sekurytyzacji w chwili obecnej jest jedną z kluczowych koncepcji w studiach nad bezpieczeństwem, wokół której nadal toczy się debata zmierzająca do jej rozwijania i udoskonalania, jak też wskazania ograniczeń i granic możliwego zastosowania. Stanowi ona interesującą próbę ujęcia w badaniach nad bezpieczeństwem międzynarodowym nowych zjawisk przy jednoczesnym zachowaniu użyteczności analitycznej samego pojęcia bezpieczeństwa. Uwaga skupia się tutaj głównie na procesie konstruowania bezpieczeństwa. Jednocześnie, obok wymiaru teoretycznego, sekurytyzacja ma także wymiar praktyczny, koncentrując się na działaniach konkretnych aktorów i ich strategiach sekurytyzacji konkretnych kwestii (np. migracji). Pozwala to na uchwycenie zmiennego charakteru samego bezpieczeństwa, ukazując również polityczny wymiar jego kształtowania. Niemniej skupienie uwagi na praktyce sekurytyzacji, na kwestii kto „sekurytyzuje”, w jakich kwestiach, w imieniu kogo/czego, dlaczego, z jakim skutkiem, i w jakich okolicznościach, może również doprowadzić do nierozpatrywania problemów, które nie zostały „,dostrzeżone” przez aktorów sekurytyzujących, lub pomijania tych obiektów bezpieczeństwa, które nie zostały uznane za legitymizowane do zapewnienia im ochrony. Pomimo jednak pojawiających się zarzutów, iż teoria sekurytyzacji podtrzymuje pewne struktury i zbytnio skupia się na „wyjątkowości” działań w zakresie bezpieczeństwa (w momencie gdy ich znaczna część ma charakter rutynowych i zbiurokratyzowanych praktyk), pozwala w interesujący sposób spojrzeć na proces kreowania bezpieczeństwa.

\section{STRESZCZENIE}

Teoria sekurytyzacji stanowi współcześnie jedno z ważniejszych podejść w studiach nad bezpieczeństwem międzynarodowym. Jest ona wykorzystywana zarówno w debacie teoretycz-

${ }^{60}$ K. Waltz, Theory of International Politics, Reading 1979, s. 92.

${ }^{61}$ B. Buzan, O. Wæver, J. De Wilde, op. cit., s. 27.

${ }^{62}$ Ibidem, s. 33 
nej na temat bezpieczeństwa, jak i analizy praktyki międzynarodowej w tym zakresie. W przypadku teorii sekurytyzacji, ukształtowanej w ramach tzw. szkoły kopenhaskiej, można mówić o nowym podejściu do bezpieczeństwa, starającym się jednak równocześnie utrzymać jego analityczną użyteczność. Obiektem analizy jest nie tyle stan, ale przede wszystkim proces konstruowania „,bezpieczeństwa”. Teoria ta koncentruje się na intersubiektywnym procesie włączania/wyłączania niektórych zagadnień do sfery bezpieczeństwa. Teoria sekurytyzacji stara się skupiać na praktyce sekurytyzacji, odpowiadając na pytania kto „sekurytyzuje”, w jakich kwestiach, w imieniu kogo/czego, dlaczego, z jakim skutkiem, i w jakich okolicznościach.

\title{
THEORY OF SECURITIZATION AND SECURITY CONSTRUCTION
}

\begin{abstract}
Theory of securitization is one of the most significant approaches to security in recent decades. It is used in the theoretical debate on the very nature of security and in the analysis of the security practice. The concept of securitization, associated with the so called Copenhagen School, is an attempt to conceptualize the security in a new way, without losing its analytical utility. The main object of investigation is the process of constructing the security as an intersubjective process of including/excluding the issues into/from the security sphere. Security is treated as a speech act, and the theory is aiming to gain the understanding who is securitizing, what issues are securitized, who is a referent object, why, with what results and under what conditions.
\end{abstract}


